\title{
Improvement of Electrical Properties of Grätzel Cells by Tuning the Dye Layer with CdS/ZnO Junction
}

\author{
M. Melouki ${ }^{1, *}$, H.F. Mehnane ${ }^{1}$, A. Djelloul ${ }^{1,2, \dagger}$, Y. Larbah ${ }^{3}$, M. Adnane ${ }^{1}$ \\ ${ }^{1}$ Département de Technologie des Matériaux, Faculté de Physique, Université des Sciences et de la Technologie \\ d'Oran Mohamed Boudiaf USTO-MB, BP 1505, El M'naouer, 31000 Oran, Algérie \\ 2 Centre de Recherche en Technologie des Semi-Conducteurs pour l'Energétique 'CRTSE', 02 Bd Frantz Fanon. \\ BP: 140. 7 Merveilles, Alger, Algérie \\ ${ }^{3}$ (CRNA) Nuclear Research Centre of Algiers, Algeria
}

(Received 21 March 2021; revised manuscript received 02 August 2021; published online 20 August 2021)

\begin{abstract}
Solar cells based on organic dye have been widely used for the reason of their simplicity of manufacture. A simple structure is composed of a colored layer of $\mathrm{TiO}_{2}$, an electrolyte and a counter electrode. In this study, the layers of $\mathrm{TiO}_{2}, \mathrm{CdS}$ and $\mathrm{ZnO}$ were deposited on conductive glass by different methods to replace organic dye. Metal organic chemical vapor deposition (MOCVD) method was used to prepare the $\mathrm{TiO}_{2}$ layer, chemical bath deposition (CBD) to prepare the CdS layer, and spray pyrolysis (SP) for the preparation of the $\mathrm{ZnO}$ layer. Morphological and structural studies have shown a homogeneous morphology of the superposition of $\mathrm{TiO}_{2} / \mathrm{CdS} / \mathrm{ZnO}$ layers. XRD and SEM characterizations have shown that annealing of the CdS layer must be done under a controlled atmosphere in order to avoid the formation of cadmium oxide and to control the particle size. The aim of this work is the substitution of organic dye in the Grätzel cell by $\mathrm{CdS}(n) / \mathrm{ZnO}\left(n^{+}\right)$junction. Morphological and optical properties of $\mathrm{TiO}_{2} / \mathrm{CdS} / \mathrm{ZnO}$ in addition to photovoltaic performance of this structure junction were investigated with different deposition times of the CdS layer. It is found that the nature of the substrate has no influence on the realization of the junction. It is noticed that each layer added leads to a decrease in the transmittance of the substrate. Characterization of the photovoltaic properties of cells based on the CdS/ZnO junction shows a higher yield compared to conventional cells based on organic dye. It is also recommended to undertake annealing under a controlled atmosphere such as nitrogen in order to eliminate the $\mathrm{CdO}$ secondary phase and decrease the size of the grains which may enhance the efficiency of the solar cells.
\end{abstract}

Keywords: $\mathrm{TiO}_{2}, \mathrm{MOCVD}, \mathrm{CBD}$, Spray pyrolysis, CdS/ZnO junction.

DOI: $10.21272 /$ jnep.13(4).04004

PACS numbers: 68.55. - a, 82.33.Ya -, 81.10.Dn,

81.15.Rs, 81.05.Hd

\section{INTRODUCTION}

Renewable energies are a solution to reduce side effect of other energies. Solar energy is one of the alternatives that can preserve the environment. Solar cell technology is in continuous progress since the appearance of its first generation. The material used is a different form of silicon. Solar cells based on thin films or second-generation solar cells are a choice to replace conventional cells based on silicon [1].

Due to their features, the third-generation solar cells or so-called Grätzel cells represent one of the solutions to promote the solar cell performance. Its structure is based on a colored photo-anode, a counter electrode and an electrolyte [2]. Several materials are used to prepare an active layer; among them titanium dioxide $\mathrm{TiO}_{2}$ [3], cadmium sulphide CdS [4] and zinc oxide $\mathrm{ZnO}$ [5].

The ruthenium-based dye is frequently used to assemble cells [6]. It will be interesting to replace its lifetime and high cost. Using a junction is one way to reduce cells cost and improve performance.

Previous studies on $\mathrm{TiO}_{2}$ have shown that it is a $3.2 \mathrm{eV}$ wide band gap semiconductor [3], it exists in three crystalline forms: anatase, rutile and brookite [2]. To increase the efficiency of Dye Sensitized Solar Cells (DSSCs), the optical, structural and crystalline studies have been favored [7]. Solar cells structures containing
CdS show better optical captivity and high current out puts $[4,8]$. CdS films deserve our attention because of their ease of manufacture and their gap, it varies between 2 and $2.8 \mathrm{eV}$ depending on the deposition methods [9]. ZnO thin films are transparent in the visible and infrared range [10]. Their energy gap at room temperature is $3.3 \mathrm{eV}$ [11].

The present work studies the properties of solar cells based on thin films of $\mathrm{TiO}_{2}, \mathrm{CdS}$ and $\mathrm{ZnO}$. The choice of a solar cell based on thin films is to find a solution for the dryness of the organic dye, and the deposition processes are extremely fast (from a few seconds to a few minutes), which makes it possible to achieve high production rates and therefore reduce production costs. Also for their efficiency, which has already reached $11 \%$ in industrial production and $20.3 \%$ under operating conditions [12].

These thin film layers have been produced by chemical methods such as Metal Organic Chemical Vapor Deposition (MOCVD), Spray Pyrolysis (SP) [5] and Chemical Bath Deposition (CBD) [13]. MOCVD is a very simple method which is done in a controlled atmosphere, and the choice of it is due to mastery of the method and because there are studies carried out on $\mathrm{TiO}_{2}$ developed by MOCVD. We opted for the SP and CBD methods for their ease of manufacture and their

\footnotetext{
* mohamed.melouki@univ-usto.dz

†djelloulcrtse@gmail.com
} 


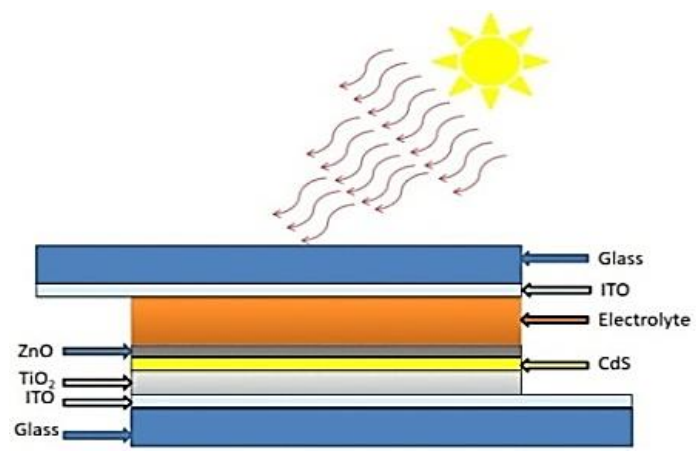

Fig. 1 - Diagram of the elaborated cell

homogeneous thin films. The cells have the following configuration: glass/ITO/TiO $/ \mathrm{CdS} / \mathrm{ZnO} /$ electrolyte/ITO/ glass. Fig. 1 shows the diagram of the performed cell.

\section{EXPERIMENTAL DETAILS}

\subsection{Preparation of Thin Films}

The substrates used are glass/ITO, glass slides covered with a layer of Indium Tin Oxide (ITO). ITO was deposited by magnetron cathode sputtering on glass of $1.1 \mathrm{~mm}$ thick, resistance $30-50 \mathrm{Ohms}$, layer thickness $\sim 1000 \AA$, manufacturer Solems. Retrogradation of the substrates for solar cell assembly and heat treatment in a $3 \mathrm{~cm} \times 2 \mathrm{~cm}$ oven under nitrogen resulted in a small width. $\mathrm{TiO}_{2}$ layers were prepared by MOCVD. Titanium isopropoxide (TIP) was used as a precursor of $\mathrm{TiO}_{2}$ concentrated to $99.999 \%$. The growth was carried out under nitrogen at a temperature of $550{ }^{\circ} \mathrm{C}$ and deposition time of $30 \mathrm{~min}$ [14]. In the second step, the optimization of $\mathrm{CdS}$ layers was done by $\mathrm{CBD}$ under several temperatures $\left(30,50,80^{\circ} \mathrm{C}\right)$. The product used as a source of cadmium was $\mathrm{CdCl}_{2}$. The composition of the bath was $\mathrm{CdCl}_{2}$, thiourea $\mathrm{CH}_{4} \mathrm{~N}_{2} \mathrm{~S}$ and ammonia $\mathrm{NH}_{4} \mathrm{OH}$, with stirring. The deposition temperature was chosen to be $50{ }^{\circ} \mathrm{C}$ according to the optical and morphological characterization of the layers carried out at 30 , 50 and $80^{\circ} \mathrm{C}$ for $60 \mathrm{~min}$. Once deposited, CdS layers were annealed under purge of air and nitrogen at a temperature of $500{ }^{\circ} \mathrm{C}$ for $30 \mathrm{~min}$. We have chosen the annealing time of $30 \mathrm{~min}$ because with less time $\mathrm{CdO}$ particles still remain. Zinc acetate was the precursor used in the SP, the preparation protocol was the same as the reference, the temperature of the hot plate was $220^{\circ} \mathrm{C}$ and the deposition time was 15 min with $30 \mathrm{~s}$ spray jets after $1 \mathrm{~min}$ of drying [15]. Then, the electrolyte layer made of potassium iodide KI and iodine I was prepared. Finally, the cells were assembled according to the configuration mentioned above.

The layers produced were characterized using a thermo brand Spectorphotometer, SEM scanning electron microscopy, JEOL JSM 7600F, a HITACHI SUI510 X-ray microprobe, a D5000X-Ray type diffractometer and UV-VIS-IFR transmittance spectroscopy. The solar simulator (Riels Instruments) was used to get the photovoltaic performance as prepared cells.

\section{RESULTS AND DISCUSSION}

Fig. 2a shows a homogeneous $\mathrm{TiO}_{2}$ layer with nanometer grains $(50 \mathrm{~nm})$ and a thickness of $150 \mathrm{~nm}$; these results are consistent with Siddhartha K. [16]. Fig. 2b shows a CdS layer deposited on glass, the thickness of the CdS layer is $80 \mathrm{~nm}$. It is composed of regularly connected islets completely covering the surface depending on the film deposition time. It can be seen that the CdS layers have a sheet-like shape on the $\mathrm{TiO}_{2}$ mat, the height of the sheets is of the order of a few hundred nanometers, and the thickness is a few tens of nanometers, which seems to completely cover the surface of $\mathrm{TiO}_{2}$. Fig. 2c clearly shows that the CdS layer after annealing at $500{ }^{\circ} \mathrm{C}$ for 60 min under nitrogen conditions does not have a constant thickness, but it seems that the entire $\mathrm{TiO}_{2}$ layer is well covered with CdS [8]. EDX analysis confirms this point. Fig. $2 d$ shows the deposition of $\mathrm{ZnO}$ by sputtering on a glass substrate. We notice a hexagonal shape of the crystal, and its crystallites rest on less structured agglomerations. Despite the homogeneous distribution, the layer does not appear to be perfectly continuous.

Fig. 3a shows the overall structure of the junction $\left(\mathrm{Si} / \mathrm{TiO}_{2} / \mathrm{CdS} / \mathrm{ZnO}\right)$. The thickness of each layer can be extracted. The thickness of the $\mathrm{TiO}_{2}$ layer is $150 \mathrm{~nm}$, the CdS layer is $80 \mathrm{~nm}$ and the $\mathrm{ZnO}$ layer is $150 \mathrm{~nm}$; the thicknesses are measured in situ using the scanning electron microscopy. Fig. $3 \mathrm{~b}$ shows the following configuration: glass/ITO/TiO $/ 2 / \mathrm{CdS} / \mathrm{ZnO}$. The thicknesses of $\mathrm{TiO}_{2}$ and CdS layers are identical to the previous configuration, while the thickness of $\mathrm{ZnO}$ increases slightly keeping the same deposition conditions. It can be noted that the nature of the substrate has no influence on the realization of our junction.
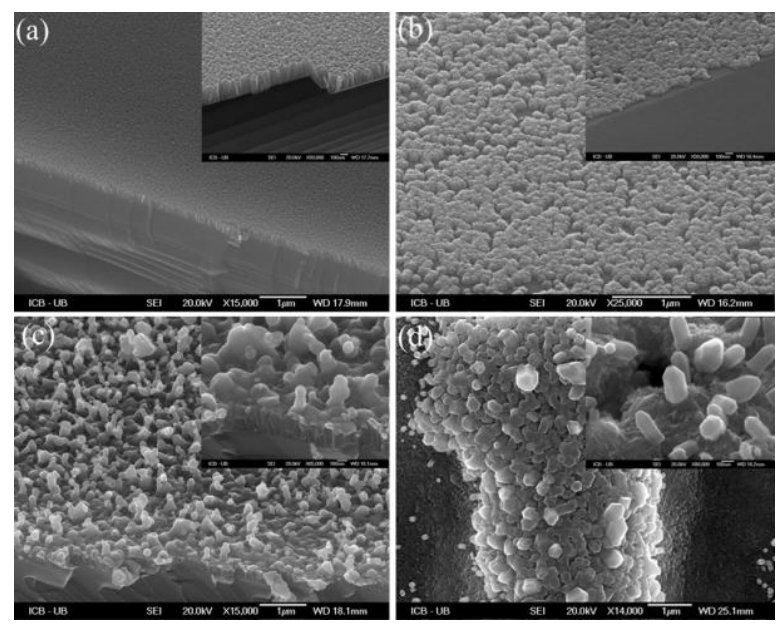

Fig. 2 - SEM images of (a) $\mathrm{TiO}_{2}$ layers on silicon, (b) $\mathrm{CdS}$ layers deposited on glass, (c) a layer of CdS deposited on the $\mathrm{Si} / \mathrm{TiO}_{2}$ substrate after annealing, and (d) $\mathrm{ZnO}$ deposits on the glass substrate

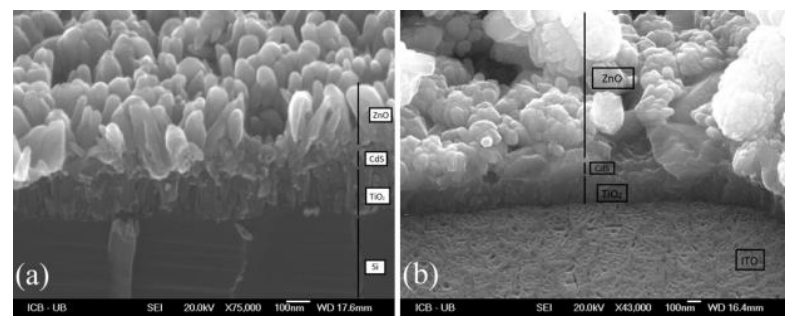

Fig. 3 - Junction of the annealed deposited layers: (a) silicon substrates, (b) glass substrates 
Table 1 shows the chemical composition of the $\mathrm{Si} / \mathrm{TiO}_{2} / \mathrm{CdS} / \mathrm{ZnO}$ junction determined by EDX elements detected before and after heat treatment and before annealing. The EDX elemental analysis reveals the presence of $\mathrm{Cd}$ probably in the form of $\mathrm{CdS}$ as well as $\mathrm{N}, \mathrm{O}, \mathrm{Cl}, \mathrm{C}$ residues of the products of synthesis (thiourea, ammonium chloride, ammonia and cadmium chloride). After annealing, the surface contains 8 at. \% of titanium. The presence of $\mathrm{Ti}$ and an increase in oxygen identify the perfect formation of CdS layers. Note the ratio $\mathrm{Cd} / \mathrm{S}=1$ indicating the presence of the only compound containing cadmium, CdS.

Table 1 - EDX evolution of the $\mathrm{Si} / \mathrm{TiO}_{2} / \mathrm{CdS} / \mathrm{ZnO}$ junction: (a) as deposed, (b) after annealing

\begin{tabular}{ccccc}
\hline & \multicolumn{2}{c}{ As deposed } & \multicolumn{2}{c}{ After annealing } \\
\cline { 2 - 5 } Elements & Norm wt\% & Norm at\% & Norm wt\% & Norm at\% \\
\hline Carbon & 2.52 & 8.46 & - & - \\
Oxygen & 17.14 & 43.27 & 15.59 & 33.27 \\
Silicon & 2.26 & 3.26 & 32.62 & 39.67 \\
Sulfur & 4.58 & 5.77 & 4.76 & 5.07 \\
Chlorine & 0.95 & 1.08 & - & - \\
Titanium & 1.56 & 1.31 & 11.96 & 8.52 \\
Zinc & 43.94 & 27.13 & 12.86 & 6.72 \\
Cadmium & 27.05 & 9.72 & 22.22 & 5.07 \\
\hline
\end{tabular}

Most of the synthetic residues decomposed and precipitated. Residual carbon can come from pollution and carbon formed during the breakdown of carbon chains in a non-oxidizing atmosphere.

At this stage of our study, we can conclude that after thermal treatment at $500{ }^{\circ} \mathrm{C}, 60 \mathrm{~min}$ under nitrogen scavenging, a CdS layer is formed by CBD, without the presence of $\mathrm{CdO}$ and contains some carbon impurities. The thickness of this layer is fine as allowed by the SEM image and the observation of titanium by EDX through the layer. It is reasonable to exclude the presence of holes in the CdS layer because before heat treatment titanium is not visible.

The results of the EDX analysis for the $\mathrm{Si} / \mathrm{TiO}_{2} / \mathrm{CdS} /$ $\mathrm{ZnO}$ junction before annealing in Table 1 represent the EDX results of the same structure after annealing. This analysis allowed us to affirm that the densification heat treatment of the $\mathrm{ZnO}$ layer does not modify the composition or the texture of this layer.

The XRD measurement is performed to determine the crystalline structure of the samples. Fig. 4 shows the crystalline structure of anatase $\mathrm{TiO}_{2}$; the peaks positions of $2 \theta$ angels $25.28^{\circ}, 38.56^{\circ} 48.06^{\circ}, 54.58^{\circ}$, $55.12^{\circ}, 62.77^{\circ}, 68.81^{\circ}, 70.42^{\circ}, 75.15^{\circ}$ and $76.18^{\circ}$ are respectively equivalent to the crystallographic planes (101), (112), (200), (105), (211), (220), (116), (220), (215) and (301). Rodrigo T. et al. [17] have already proven these results. The studies carried out by A. Crisbasan have shown that the $\mathrm{TiO}_{2}$ layer obtained by MOCVD consists of monocrystalline columns perpendicular to the substrate [14]. Before doing our grain size calculations, we will correct the FWHM measurements by instrumental enlargement before applying the formula. Using the Scherrer's formula [5, 13], the grain size $t$ was calculated and is shown in Table 2 ; its range from 30 to $60 \mathrm{~nm}$ is similar to Kibasomba study [18].

Fig. 5 shows the XRD peaks of CdS layers: asdeposed (a), after annealing under nitrogen (b), and after annealing under air (c). The diffractogram indicates the presence of CdS peaks only after heat treat- ment, which is visible by comparing (a) before annealing with (b) after annealing under nitrogen and (c) after annealing under air. The presence of peaks characteristic of the majority CdS phase is noted as well as the presence of peaks characteristic of the $\mathrm{CdO}$ phase after heat treatment in air. The size of CdS crystals is smaller after treatment under nitrogen compared to treatment in air. This is due to the presence of $\mathrm{CdO}$ particles [19]. The type of annealing affects the size of crystallites. Table 3 shows the size of the crystals annealed under nitrogen and annealed under air. The grain size of CdS upon annealing in nitrogen is from 18 to $31 \mathrm{~nm}$, and upon annealing in air from 38 to $82 \mathrm{~nm}$. Nonmetric dimensions of the films are very important in the results in order to improve proprieties and operating materials.

XRD analysis confirms the formation of pure CdS compound for samples treated in nitrogen. Consequently, densification of the $\mathrm{ZnO}$ layer must be done in a non-oxidizing atmosphere to avoid the appearance of CdO particles.

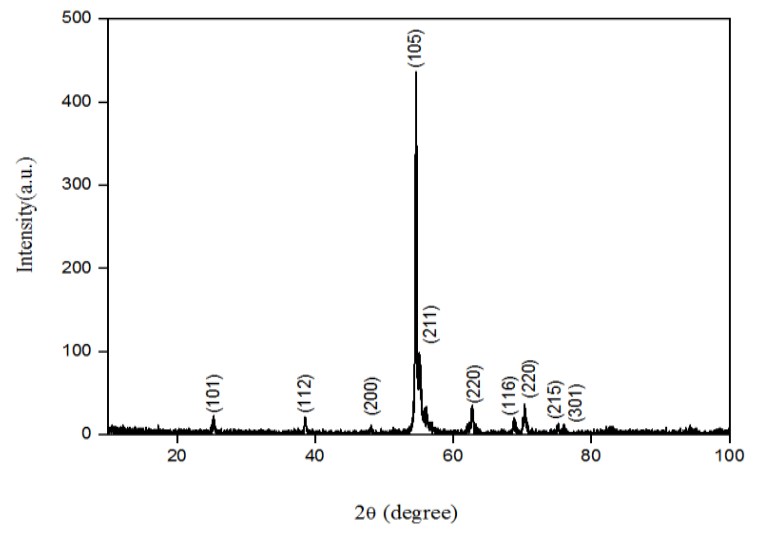

Fig. 4 - X-ray diffraction pattern of $\mathrm{TiO}_{2}$ samples deposited on silicon

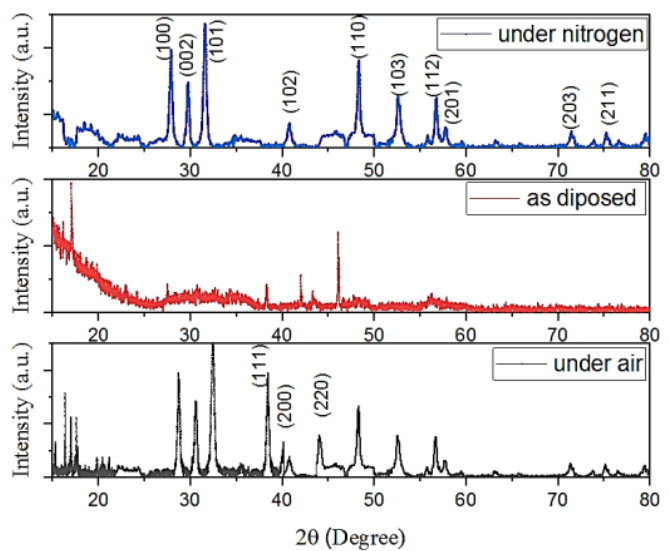

Fig. 5 - X-ray diffraction spectra of the CdS layer deposed on glass substrate: (a) deposed just before annealing, (b) after annealing in nitrogen, (c) after annealing in air

Table $2-\mathrm{TiO}_{2}$ crystallite size of the sample

\begin{tabular}{ccccccccccc}
\hline hkl & 101 & 112 & 200 & 105 & 211 & 220 & 116 & 220 & 215 & 301 \\
\hline $\mathrm{t}(\mathrm{nm})$ & 32 & 36 & 40 & 58 & 58 & 46 & 50 & 64 & 64 & 62 \\
\hline
\end{tabular}

The transmittance of our studied glass/ITO/TiO $/$ $\mathrm{CdS} / \mathrm{ZnO}$ junction is shown in Fig. 6. From the spec- 
trum, we notice that each time we add a layer the transmittance of the substrate decreases, and this is logical due to the thickness of the layers.

Table 3 - Sizes of crystals annealed under nitrogen and air

\begin{tabular}{crrrrrrrrrrrrrr}
\hline hkl & 100 & 002 & 101 & 111 & 200 & 102 & 220 & 110 & 103 & 200 & 112 & 104 & 203 & 211 \\
\hline $\mathrm{t}(\mathrm{a})(\mathrm{nm})$ & 31 & 23 & 26 & - & - & 25 & - & 25 & 21 & 18 & 24 & 29 & 22 & 24 \\
\hline $\mathrm{t}(\mathrm{b})(\mathrm{nm})$ & 74 & 67 & 53 & 82 & 69 & 60 & 64 & 78 & 46 & 47 & 38 & 46 & 89 & 84 \\
\hline
\end{tabular}

Table 4 - Photovoltaic performance of the $\mathrm{TiO}_{2} / \mathrm{CdS} / \mathrm{ZnO}$ junction for different deposition times of the CdS layer

\begin{tabular}{crrrr}
\hline Cells & $\begin{array}{r}\text { Jsc } \\
\left(\mathrm{mA} / \mathrm{cm}^{2}\right)\end{array}$ & $\begin{array}{r}\text { Voc } \\
(\mathrm{V})\end{array}$ & $\begin{array}{r}\eta \\
(\%)\end{array}$ & $\begin{array}{r}\mathrm{FF} \\
(\%)\end{array}$ \\
\hline $\mathrm{TiO}_{2} / \mathrm{CdS}\left(20^{\circ}\right) / \mathrm{ZnO}$ & 3.78 & 0.18 & 0.32 & 0.47 \\
$\mathrm{TiO}_{2} / \mathrm{CdS}\left(30^{\circ}\right) / \mathrm{ZnO}$ & 3.76 & 0.22 & 0.37 & 0.68 \\
$\mathrm{TiO}_{2} / \mathrm{CdS}\left(50^{\circ}\right) / \mathrm{ZnO}$ & 3.18 & 0.17 & 0.22 & 0.41 \\
\hline
\end{tabular}

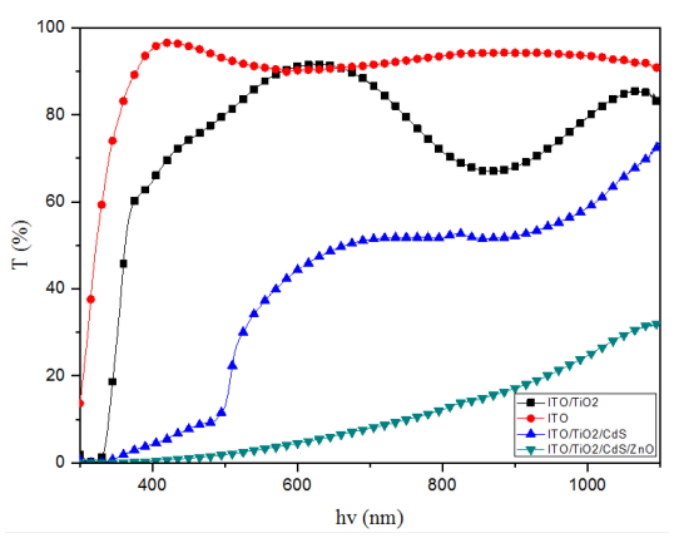

Fig. 6 - Transmittance spectra of the glass/ITO/TiO $/ 2 / \mathrm{CdS} / \mathrm{ZnO}$ junction in the UV-Vis-IR spectrum

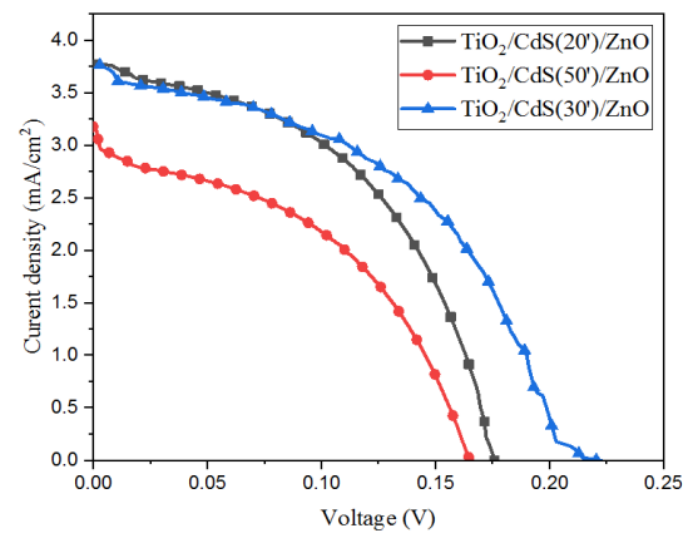

Fig. $7-J-V$ curves of the fabricated $\mathrm{TiO}_{2} / \mathrm{CdS} / \mathrm{ZnO}$ junction with different deposition times of the CdS layer

After the completion of our junction, we prepare the electrolyte based on polyethylene glycol $\mathrm{C}_{2 n} \mathrm{H}_{4 n+2} \mathrm{O}_{n+1}$, potassium iodide KI, iodine I and ethanol. In the end, the assembly of solar cells is done by depositing the electrolyte on the sandwich prepared beforehand of $\mathrm{ITO} / \mathrm{TiO}_{2} / \mathrm{CdS} / \mathrm{ZnO}$ thin films. Then we deposit an ITOconducting substrate and make our contact with silver lacquer as shown in diagram of the cells in Fig. 1.

The electrical measurements were carried out using a solar simulator (Riels Instruments) at the CRTSE research center. Fig. 7 represents the current densityvoltage $J(V)$ characteristics of solar cells produced under lighting. The cells were selected based on the window layer deposition time (CdS). The deposition time for cells of group (1) $\left(\mathrm{TiO}_{2} / \mathrm{CdS}\left(20^{\prime}\right) / \mathrm{ZnO}\right)$ was $20 \mathrm{~min}$, cells of group (2) $\left(\mathrm{TiO}_{2} / \mathrm{CdS}\left(30^{\prime}\right) / \mathrm{ZnO}\right)$ was $30 \mathrm{~min}$ and cells of group (3) $\left(\mathrm{TiO}_{2} / \mathrm{CdS}\left(50^{\prime}\right) / \mathrm{ZnO}\right)$ was $50 \mathrm{~min}$.

Table 4 shows the photovoltaic performance of the $\mathrm{TiO}_{2} / \mathrm{CdS} / \mathrm{ZnO}$ junction for different deposition times of the CdS layer. It is noted that the performances of group (2) have the best efficiency in comparison with other cells of group (1) and group (3). Cells of group (3) have lower efficiency $(1.76 \%$ less than cells of group (2)); this is due to the low current intensity and voltage generated by cells of group (3). In the work of Guang $\mathrm{Zhu}$ et al. [20], they developed cells of $\mathrm{TiO}_{2} / \mathrm{CdS}$ and $\mathrm{TiO}_{2} / \mathrm{ZnO} / \mathrm{CdS}$ types. The results found are $\mathrm{TiO}_{2}$ with the efficiency $\eta=0.99 \%$, fill factor $\mathrm{FF}=0.36 \%$, opencircuit voltage $V_{\mathrm{oc}}=0.49 \mathrm{~V}$ and short-circuit current density $J_{\mathrm{sc}}=5.52 \mathrm{~mA} / \mathrm{cm}^{2}$, and in the cell with the $\mathrm{TiO}_{2} / \mathrm{CdS} / \mathrm{ZnO}$ junction the efficiency $\eta=1.56 \%$, $\mathrm{FF}=0.35 \%, V \mathrm{oc}=0.58 \mathrm{~V}$ and $J_{\mathrm{sc}}=7.66 \mathrm{~mA} / \mathrm{cm}^{2}$.

\section{CONCLUSIONS}

The substitution of organic dye by the $\mathrm{CdS} / \mathrm{ZnO}$ junction was carried out in this work. CBD and SP techniques were used to prepare these layers. Then, each thin layer was characterized morphologically, structurally, and optically.

Through these characterizations, we have shown that annealing of the CdS layer must be done under a controlled atmosphere in order to avoid the formation of cadmium oxide and to control the particle size.

Following the characterization of the photovoltaic properties of cells based on the $\mathrm{CdS} / \mathrm{ZnO}$ junction, a higher yield is shown compared to conventional cells based on organic dye. It is also noted that annealing under a controlled atmosphere such as nitrogen will eliminate $\mathrm{CdO}$ particles and also decrease the grain size. The efficiencies of our solar cells are $\eta_{1}=0.37 \%$, $\eta_{2}=0.22 \%$, and $\eta_{3}=0.32 \%$.

\section{ACKNOWLEDGEMENTS}

The authors wish to thank the General Directorate for Scientific Research and Technological Development (DGRSDT) and the Research Center on Semiconductor Technology for Energy (CRTSE).

\section{REFERENCES}

1. A.A. Ojo, W.M. Cranton, I.M. Dharmadasa, Next Generation Multilayer Graded Bandgap Solar Cells 1st Ed. 2019 Edition, 5 (2018).

2. D. Reyes-Coronado, G. Rodriguez-Gattorno, M.E. EspinosaPesqueira, C. Cab, R. de Coss, G. Oskam, Nanotechnology 19, 145605 (2002).

3. H.T. Grahn, World Scientific Publishing Co Inc 1999, (2016).

4. R.S. Meshram, B.M. Suryavanshi, R.M. Thombre, Adv. Appl. Sci. Res. 3, 1563 (2012).

5. Y. Larbah, M. Adnane, A. Djelloul, M. Melouki, J. NanoElectron. Phys. 7, 03013 (2015).

6. L. Wei, N. Yong, Y. Yang, R. Fan, P. Wang, L. Li, Phys. Chem. 
Chem. Phys. 17, 1273 (2015).

7. W. Wang, M. Wang, X. Feng, W. Zhao, C. Luan, J. Ma, Mater. Chem. Phys. 211, 172 (2018)

8. A. Mutalikdesai, S.K. Ramasesha, Thin Solid Films 632, 73 (2017).

9. H. Khallaf, I.O. Oladeji, G. Chai, L. Chow, Thin Solid Films 516, 7306 (2008).

10. P. Petrou, R. Singh, D.E. Brodie, Appl Phys. Lett. 35, 930 (1979).

11. N. Kamoun Allouche, T. Ben Nasr, N. Kamoun Turki, M. Castagne, Energy Procedia 2, 91 (2010).

12. G. Han, S. Zhang, P.P. Boix, L.H. Wong, L. Sun, S.-Y. Lien, Prog. Mater. Sci. 87, 246 (2017).

13. A. Djelloul, M. Adnane, Y. Larbah, M. Zerdali, C. Zegadi, A. Messaoud, J. Nano- Electron. Phys. 8, 02005 (2016).
14. A. Crisbasana, D. Chaumont, M. Sacilotti, A. Crisan, A.M. Lazar, I. Ciobanu, Y. Lacroute, R. Chassagnon, Appl. Surf. Sci. 358, 655 (2015).

15. Guang Zhu, Tian Lv, Likun Pan, Zhuo Sun, Changqing Sun, J. Alloy. Compd. 509, 362 (2011).

16. S.K. Pradhan, P.J. Reucroft, J. Crystal Growth 250, 588 (2003).

17. Rodrigo T. Bento, Olandir V. Correa, Marina F. Pillis, J. Eur. Ceram. Soc. 39, 3498 (2019).

18. P.M. Kibasomba, S. Dhlamini, M. Maaza, C-P. Liu, M.M. Rashad, D.A. Rayan, B.W. Mwakikunga, Res. Phys. 9, 628 (2018).

19. H. Metin, R. Esen, J. Crystal Growth 258, 141 (2003).

20. Guang Zhu, Likun Pan, Tao Xu, Qingfei Zhao, Zhuo Sun, J. Alloy. Compd. 509, 7814 (2011).

\title{
Покращення електричних властивостей елементів Гретцеля шляхом заміщення шару барвника переходом $\mathrm{CdS} / \mathrm{ZnO}$
}

\author{
M. Melouki ${ }^{1}$, H.F. Mehnane ${ }^{1}$, A. Djelloul ${ }^{1,2}$, Y. Larbah ${ }^{3}$, M. Adnane ${ }^{1}$ \\ ${ }^{1}$ Département de Technologie des Matériaux, Faculté de Physique, Université des Sciences et de la Technologie \\ d'Oran Mohamed Boudiaf USTO-MB, BP 1505, El M'naouer, 31000 Oran Algérie \\ ${ }^{2}$ Centre de Recherche en Technologie des Semi-Conducteurs pour l'Energétique 'CRTSE' 02 Bd Frantz Fanon. \\ BP: 140. 7 Merveilles, Alger, Algérie \\ 3 (CRNA) Nuclear Research Centre of Algiers, Algeria
}

\begin{abstract}
Сонячні елементи на основі органічного барвника широко використовуються через простоту їх виготовлення. Проста структура складаеться з кольорового шару $\mathrm{TiO}_{2}$, електроліту та антиелектроду. У дослідженні шари $\mathrm{TiO}_{2}$, CdS та $\mathrm{ZnO}$ наносились на електропровідне скло різними методами для заміни органічного барвника. Для підготовки шару $\mathrm{TiO}_{2}$ використовували метод метал-органічного хімічного осадження з газової фрази (MOCVD), хімічне осадження у ванні (CBD) для підготовки шару CdS та спрей-піроліз (SP) для приготування шару ZnO. Морфологічні та структурні дослідження показали однорідну морфологію суперпозиції шарів $\mathrm{TiO}_{2} / \mathrm{CdS} / \mathrm{ZnO}$. XRD та SEM аналіз показав, що відпал шару $\mathrm{CdS}$ повинен проводитися в контрольованій атмосфері, щоб уникнути утворення оксиду кадмію та регулювати розмір частинок. Метою роботи є заміщення органічного барвника в елементі Гретцеля переходом $\mathrm{CdS}(n) / \mathrm{ZnO}\left(n^{+}\right)$. Морфологічні та оптичні властивості $\mathrm{TiO}_{2} / \mathrm{CdS} / \mathrm{ZnO}$ на додаток до фотоелектричних характеристик цього структурного переходу були досліджені з різним часом осадження шару $\mathrm{CdS}$. Встановлено, що природа підкладки не впливае на реалізацію переходу. Помічено, що кожен доданий шар призводить до зменшення коефіцієнту пропускання підкладки. Характеристика фотоелектричних властивостей елементів на основі переходу $\mathrm{CdS} / \mathrm{ZnO}$ показуе більш високий вихід в порівнянні зі звичайними елементами на основі органічного барвника. Також рекомендовано проводити відпал в контрольованій атмосфері, такій як азот, щоб усунути вторинну фазу $\mathrm{CdO}$ і зменшити розмір зерен, що може підвищити ефективність сонячних елементів.
\end{abstract}

Ключові слова: $\mathrm{TiO}_{2}, \mathrm{MOCVD}, \mathrm{CBD}$, Спрей-піроліз, Перехід CdS/ZnO. 